\title{
THE ROLE OF COASTAL. AND SMALL ISLANDS ZONATION PLAN FOR MANAGEMENT OF MARINE PROTECTED AREA: THE INDONESIAN CASE
}

\author{
Budy Wiryawan ${ }^{11}$, Audrie Siahainenia ${ }^{2)}$, Amiruddin Tahir ${ }^{11}$, and Nina Dwisasanti ${ }^{3 /}$ \\ Faculty of Fisheries and Marine Science, Bogor Agricultural University, Bogor \\ 2) World Wildlife Fund for Nature Indonesia \\ 3) The Nature Conservancy Indonesia \\ Received November 30-2009; Received in revised form March 26-2010; Accepted April 6-2010
}

\begin{abstract}
The expansion of coastal and small islands resources utilization and the increasing need to meet international and national commitments to biodiversity conservation have led to an enhanced interest in zonation plan as a tool for integrated coastal management. The Berau Regency in East Kalimantan, Indonesia, has a local initiative and driven by National Law No.27/2007 taken global leadership in implementing of Berau Marine Protected Area. This paper will discuss the Berau Marine Protected Area experiences with zonation plan. It will give a short historical overview based on legal developments and review the implementation process of a zonation plan as a spatial management policy for the Berau Marine Protected Area. Additionally, this paper will reflect on the research that has been carried out in the study area to apply a spatial and conservation planning approach to the coastal and small island environment. The zonation planning process in Berau shows that a spatial approach to coastal and small islands management is possible despite the lack of a legal zoning framework. However, it concludes that a legal basis for zonation plan in the future would provide a more strategic and integrated framework for ecosystem-approach for fisheries and coastal and small islands management.
\end{abstract}

KEYWORDS: $\quad$ marine protected area, zonation planning, coastal, small islands

\section{INTRODUCTION}

Management of coastal areas and small islands as mentioned in aticle 5 of National Law No.27/2007 includes the planning, utilization, supervision, nd control of human interaction in the use of coastal resources and small islands and sustainable natural process in an effort to improve public welfare and maintaining the integrity of the Republic of Indonesia.

Coastal and small island zonation plan, as stated in article 7 of National Law No.27/2007 comprising 4 types of planning, which are a) coastal and small islands zone strategic plan, b) coastal and small island zonation plan or, c) coastal and small islands zone management plan or, and d) coastal and small islands zone management plan of action.

Berau District, one district in East Kalimantan Province, has coastal areas and small islands. In order to implement the coastal management planning and small islands as mandated by Law No.27/2007, the government initiated the preparation of Berau district of coastal area planning and zonation of small islands in Berau District.

The coastal and small islands zonation plan of Berau Regency consist the directive about spatial allocation within public utilized zonation plan, conservation zone plan, particular national strategic zone plan, and pattern plan; and the interconnection of coastal and small islands ecosystem within the bioecoregion. Planning of Berau Regency's zonation planning is undertaken by considering 1) suitability, conformity and balance with the environmental carrying capacity, utility and protective function, time and space dimension, technology and socio cultural dimension, and the function of security and defensive capacity, 2) integrated utilization of various resources, function, environmental aesthethics, and coastal land quality, and 3) the obligation to allocate space and access for the society in utilizing the coastal and small islands zone which governs social and economic function. Thus the Berau Regency's zonation planning is meant to resolve the conflicts of authority the conflicts in resources utilization and governing the utilization of coastal and small islands resources in the long term, organizing the spatial dimension of coastal and small islands resources management and development within a particular time frame. The zonation planning also contains the directives for planning and utilizing each zone of sea water, coast and small islands.

The objective of Berau Regency's zonation planning is 1) spatial allocation of coastal and small

Corresponding author:

Jl. Agatis, Kampus Institut Pertanian Bogor Darmaga, Bogor-16680 
islands zone for public utilization, conservation area, particular national strategic, sea patterns according to the designation and activities that supports each other and also separate it from contradicting activities, 2) dividing each area into utilization of zones and sub zones according to the development priorities of the partiular area, 3) determining the zones within coastal and small islands area by considering ecological, economic and socio cultural interconnection. Ecologic interconnetion is then expanded to manage islands within the same bioecoregion, and 4) optimizing spatial utilization in the effort and investment development through licensing mechanism and granting of HP3 (Use Right of Coastal Waters stated in Law No.27/2007).

\section{Study Area}

Berau Regency is one of 13 regencies of east Borneo. The area consists of 3.426 .070 ha with marine area of $1.222 .988 \mathrm{ha}$. The boundaries of this regency are Bulungan Regency at the west and north, Sulawesi Sea at the east part, and East Kutai Regency at the south. Administratively Berau Regency consists of 13 districts, which are Tanjung Redeb, Gunung Tabur, Teluk Bayur, Segah, Kelay, Sambaliung, Derawan, Maratua, Tabalar, Biatan-Lempake, Tali Sayan, Batu Putih, and Biduk-Biduk. The last eight districts are districts that have coastal area. Maratua district in particular is located at sea. The districts of Batu Putin and Biatan-Lempake are newly formed districts which are formed at 2005

There are two main rivers which run towards the coastal area of Berau Regency, which are Berau River and Tabalar River. Berau River is the major that stretch afar from Sungai Segah and Sungai Kelay river basin: it converges at Tanjung Redeb and into the sea. This river is one of the main transportation from Tanjung Redeb to other areas outside Berau Regency, including islands such as Derawan, Sangalaki, Kakaban, and Maratua. The turbidity level of Berau River is very high, thus at a particular months, sediment from the river could be seen at Derawan Island's reef.

Berau Regency has 39 islands, while there are 31 at Berau Marine Protected Area spreading in the north and south of conservation area. There are also a number of banks and atolls. These islands are spread in 4 coastal districts, which are Derawan and Maratua Island in the north, and Batu Putih and Biduk-Biduk District at the south. In these 31 island, there are only 4 inhabitated islands, which are Derawan, Maratua, Kaniungan Besar, and Balikukup Islands.
Mangrove forest at Berau could be found at Tanjung Batu and delta Berau in the north until Biduk-Biduk in the south. Mangrove forest could also be found in islands such as Pulau Panjang, Rabu-Rabu. Semama, and Martua in the northern part of Berau coastline and Buaya-Buaya Island in the southern part. Overall mangrove area at Berau Marine Protected Area covers about $80,277 \mathrm{ha}$, consisting of true mangrove (bakau, api-api) 49.888 ha and pseudo mangrove (nipah, nibung) 30,389 ha. Nipah in particular dominates along the delta of main rivers, while the true mangrove found in Berau delta and along the coastline.

Seagrass meadows could be found spread all over Berau coast with varying conditions, with the average reef coverage of less than 10-80\%. Low level of sea grass coverage $(<10 \%)$ could be found in areas with high level of disturbance such as being exposed at the lowest tide. while high level of sea grass coverage $(20-80 \%)$ could be found in areas constantly puddled and covered by water. Based on survey at 2003 (Wiryawan et al., 2005) there are 8 species of seagrass found on the Berau coastline, which are Halodule univervis, Halodule pinifolia, Cyamodocea rotundata, Syringodium isoetifolium, Enhalus acoroides, Thalassia hemprichii, Halophila ovata, and Halophila ovalis.

Coral reef at Berau coastline widely spread all over the island and in the northern and souther banks. Coral banks found in the northern part of Berau coast are Gosong Mangkalasa, Gosong Masimbung, Gosong Buliulin, Gosong Pinaka, Gosong Tababinga, Gosong Lintang, Gosong Muaras, and Gosong Malalungun. While in the southern part is Gosong Besar/Sapitan, Gosong Dangalahan and Gosong Paninsinan. Types of coral reef in Berau coastline are side reef, barrier reef, and atoll. Some atolls formed islands while other atolls formed salt lakes. Atolls of Berau coast could only be found in the northern part, they are Pulau Kakaban, Pulau Maratua, and Gosong Muaras. Kakaban Atol covers $19 \mathrm{~km}^{2}$, Atol Maratua $690 \mathrm{~km}$, and Atol Muaras $288 \mathrm{~km}^{2}$.

From survey result, it was known that lives coral coverage in the northern area was $22,78 \%$, while in the southern part was $27,85 \%$. As for dead coral coverage in the northern part was 45,65 and $35,05 \%$ in the southern part. Reef fishes survey in October 2003 found 832 species classified in 272 genera and 71 family. In addition there are 40 species, 16 genera and 6 family from the 1994 survey at SangalakiKakaban, overall there were 872 species in total (Allen, 2004). 


\section{MATERIALS AND METHODS}

The research was carried out in March until June 2009. The data was collected in two ways, namely secondary data collection and verification of field data. Field data verification done to validate secondary data has been obtained from various sources (TNC, Berau Government, WWF, Bestari, Mulawarman University, and Conservation International). Field data verification was done by checking directly the condition of the field and had a discussion with the community. Kind of data collected were geomorphology, hydrology, land use, and coastal ecosystem. These data were obtained from the thematic maps that have been produced previously, either by Bakosurtanal and the District Government of Berau. Oceanographic data and water quality were also obtained from the measurements taken by the Joint Secretariat (Government of Berau, the Nature Conservancy, Conservation International, and the Worldwide Fund for Nature Indonesia). The data then analyzed by using spatial analysis approach, using a matrix suitability for use of each allotment of land and coastal waters.

\section{RESULTS AND DISCUSSION}

Coastal and small islands zonation plan of Berau Regency includes coastal area and small islands which is consists of 8 districts, namely Biduk-Biduk, Batu Putih, Talisayan, Biatan, Tabalar, Sabaliung, Kecamatan Pulau Derawan, and Maratua. Resulting zones are multiple/general use zone, conservation zone, strategic zone, and corridor zone.

\section{General Use Zone}

Based on coastal and small islands resources potential in Berau Regency such as biophysical aspect, economic, socio cultural aspect, and existing policies, then the general use zone possible for coastal and small islands area of Berau Regency consists of port zone, fisheries, aquaculture, dwellings and farming, agriculture, industry, tourism, and forestry. Port zone consists of 2 sub zones which are public port and coal port. The existing public port is still very simple and traditional. The port only has wood constructed jetty.

Fisheries zone consists of 5 sub zones which are traditional fisheries zone, commercial fishing, reef fisheries, stationary lift net, and fish aggregating device. The traditional fishing zone domintaed by local fishermen operating at depth of about $20 \mathrm{~m}$. Pelagic fishes are the main commodity for fishermen.
Commercial fishing operates at longer distance and fishermen from outside the area could be involved. Reef fishery is quite dominant in this area, considering there are numerous banks with quite vast area. This condition is in line with local government policies that declares Berau regency as reef fishing zonation. Lift net fisheries could be found around Tanjung batu village, while fish shelters could be found around Labuan Kelambu village. Although, at present, the aggregating device being implemented is very simple.

Aquaculture zone, consists of cage mariculture, seagrass culture, and ponds. Currently, the KJA could only be found around Pulau Balikukup. Protected lagoons around coral banks are potential area for the development of KJA. There is currently no effort for seagrass culturing. Protected areas around islands covered by dead coral has the potential to be developed as seagrass culture. Ponds has been operating in a number of areas such as Pulau Guntung and Tabalar.

Residential and farming zone consists of wet and dry land farming. Wet land farming generally in the form of rice field, while dry land farming generally in the form of lading. Among the plantation commodities are rice and pepper.

The existing plantation zone is traditional plantation. For the industrial zone, the developing activities are forestry industry which is wood industry. But along the shrinking of forest resources, particularly woods, this industry in suffering declines.

Tourism zone consists mainly marine tourism. Beach tourism is mainly focused in the delivery of supporting facilities such as hotels, restaurants, etc. while marine tourism is the object of recreational activities. The beauty of reef and marine biota of Berau Regency is appreciated internationally. This is an asset that is very valuable to be developed sustainably.

Forestry zone consists of production forest, limited production forest, and industrial forest. Wise management is needed to retain forest sustainability that is undergoing area shrinkage from time to time.

\section{Selected Conservation Targets:}

1. Mangrove and Coral reef in Tanjung Batu

This area consists of a unique set of coral reef ecosystem. Water in this area is mildly turbid, but it contains corals seldom found on other area, and also corals that are of high economic value. Other than that, based on workshops conducted by marine conservation experts, the coral 
ecosystem perpendicular with the mangroves had a relatively unique composition of corals.

\section{Pulau Panjang}

Pulau Panjang is well known as feeding ground for green sea turtles that inhabits Derawan complex. Almost anywhere around Pulau Panjang. could be found seaweeds ecosystem with relatively healthy condition. There are also locations with high reef fishes species diversity.

\section{Pulau Semama}

Pulau Semama is designated as nature reserve area by the department of forestry. This island is an important location for birds. Pulau Semama acts as nesting area and resting area for migratory birds.

\section{Pulau Sangalaki}

Pulau Sangalaki is designated as marine recreational park by the Ministry of Forestry. Coral reefs around Pulau Sangalaki might to be manta ray's breeding ground. Pulau Sangalaki is also one of the world's largest nesting ground for turtles. A unique kind of bird is also to be found in this island, this bird is a sub species of megaoda birds, which needs further research.

5. Pulau Guntung, Pulau Pagat, Mangkajang Delta, and Mangrove at Tabalar

Mangrove areas around Berau delta are natural ecosystems. Which acts as nursery ground for fishes around Pulau Derawan.

\section{Gosong Malalungun}

Gosong Malalungun is located in the middle, unattached from the barrier reef between Pulau Panjang to Pulau Sangalaki thus having a relatively unique composition. Coral reef and reef fishes in this area are highly diverse and has colonies of red coral.

\section{Pulau Kakaban}

Pulau Kakaban is one of the geologically and biologically unique islands in the world with salt water lake in it. Geologically, Pulau Kakaban is a closed atoll lifted from the bottom of the sea. Within Pulau Kakaban's salt lake could be found a number of endemic faunas that is only found in two locations in the world. Pulau Kakaban also has a very exotic coral reef functioning as fish spawning ground.
8. Pulau Maratua

Pulau Maratua is a unique island and is a semi closed off atoll. Pulau Maratua is known to divers as giant fish country. At coral reef area in the west of Maratua could be found scores of green sea turtles at the depth of $5-20 \mathrm{~m}$. at the eastern part of Pulau Maratua could be found a channel that resembles river flow which is predicted as cod fish breeding area. To the north, dolphins are often spotted and whales, sharks, or tiger sharks could also be spotted from time to time. Pulau Maratua also has two salt lakes similar to Pulau Kakaban.

\section{Pulau Sambit and Blambangan}

Pulau Sambit-Blambangan is one of the fore most island located in the southernmost part of gosong muaras. This island is one of the main location for nesting turtles.

\section{Pulau Bilang-Bilangan and Mataha}

Pulau Bilang-Bilangan and Mataha are two islands located to the south of Berau Regericy. This island is the main nesting location for turtle after Pulau Sangalaki.

\section{Northern part of Karang Besar}

Karang Besar has a complicated structure of corals. The northern part of Karang Besar is a breeding ground for cods and napoleon fish.

\section{Mangrove Batu Putih and Pulau Buaya-Buaya} Mangroves at Batu Putih and Pulau Buaya-Buaya are areas of mangroves in relatively good condition. Mangrove at this location is closely related to Karang Besar and thought to be one of the main nursery ground. This location also serve as nesting area for crocodiles (Crocodylus porosus).

\section{Bay Sulaiman}

Bay Sulaiman is one of the unique location close to Borneo mainland. Within Bay Sulaiman could be found a complex ecosystem between mangrove, seagrass, and coral reef. Around this bay could be found nesting and feeding area for turtles.

14. Pulau Kanjungan Kecil-Teluk Sumbang Pulau Kanjungan and Teluk Sumbang located at the southernmost part of Berau coastline. At this location, dolphins and whales swimming around the area, and could be made into tourism spot for whales and dolphins attraction. 
15. Forest Coservation Area

Conservation forest is very important to maintain the balance of ecosystem in a certain area. Conservation forest is a very fragile area thus needs to be guarded and offer local protection. The conservation forest at Berau District located at the upstream area.

\section{Special Status/Forest Research}

Special status for forest research granted because the forest at Berau Regency's coastal area is one of the forest rich in biodiversity. It is also thought to be the habitat of various protected faunas such as orang utan. Thus it is needed a special location for research forest.

\section{Sempadan Pantai}

Sempadan Pantai is mainly designated as beach tourism, not as conservation zone. As stated in Kepres. No.32/1990 that sempadan pantai proportional in width with the beach physical form 100 meters, minimum from highest tide towards land.

\section{National Strategic Zone}

National strategic areas located at the coast of Berau Regency are border zone and small outer islands (Figure 1). There are two islands which classified as small outer islands; they are Pulau Maratua and Pulau Sambit. Pulau Maratua is inhabited, while there is no inhabitant at Pulau Sambit.

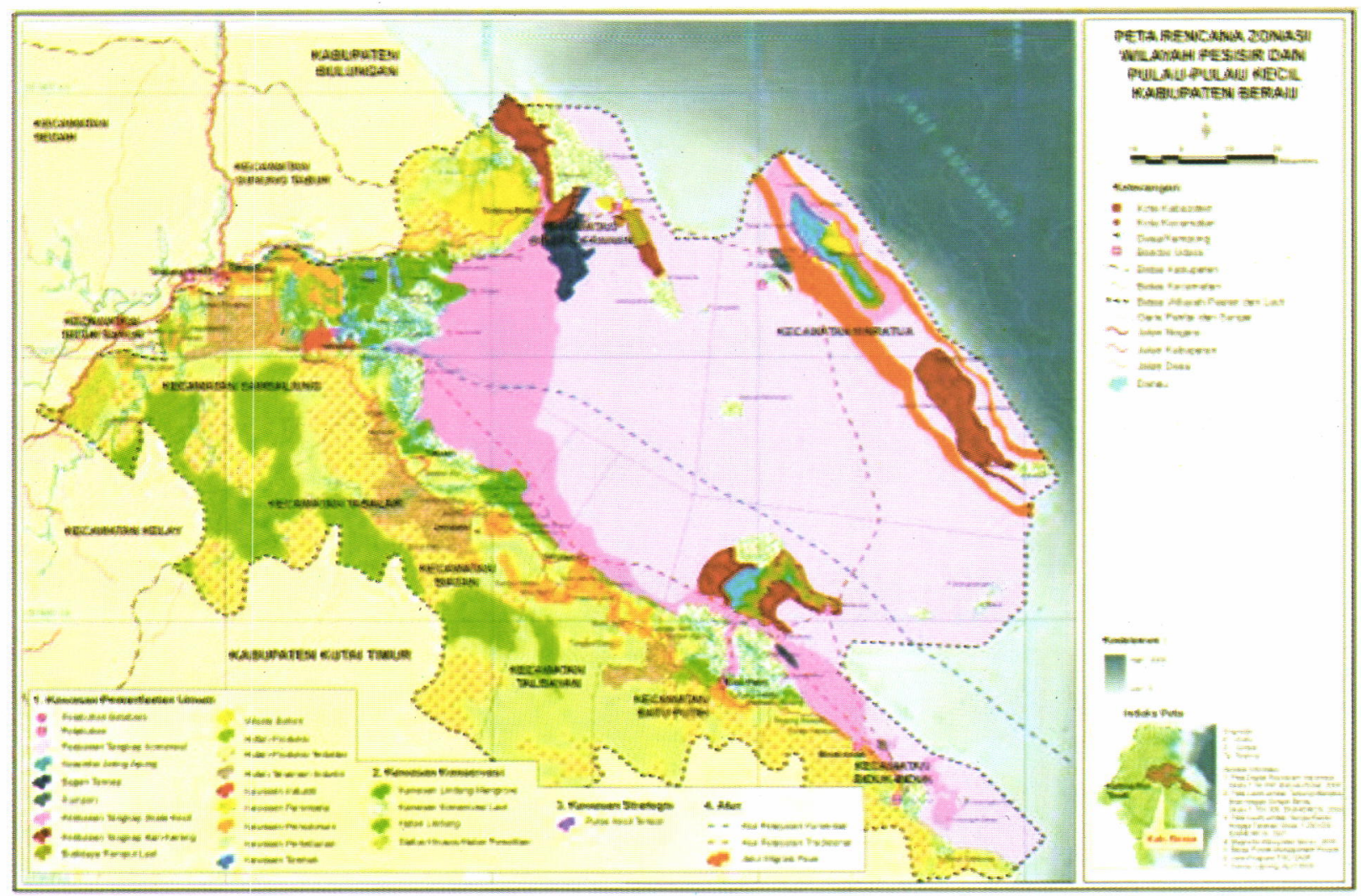

Figure 1.

Propose zonation plan for coastal and small Islands Berau.

\section{DISCUSSION}

Coastal zoning and small islands of Berau mentioned above (Figure 1) which consists of general use zone, conservation zone and national strategic zone, and the plot is in compliance with the mandated in the Law No.27/2007. As mentioned above that the zoning of coastal areas and the small islands in the study area has four objectives, namely the division of the region, set the region into sub zones, based on the unity it would be harmoni size the ecological management and optimize the utilization of space. In line with the concept of zoning in the top, Norse (2005) suggested a comprehensive program of resource management and protection based on zoning. Where zoning is defined as an authorization and allocation rules and access to specific use of sea waters geographically. Thus, zoning is an approach that can be used to manage coastal areas and sustainable small islands. Coastal and marine areas are not 
managed according to zoning often have negative impacts. The problems that often arise from the absence of zoning and management of coastal areas is the emergence of small islands conflicts of space utilization. It is also mentioned by Bess \& Rallapudi (2007) where frequent use of the conflict arises because there was no zoning of coastal resource use and small islands.

Coastal zoning plan and small islands of Berau conducted through a holistic approach, taking into account the suitability and environmental carrying capacity will strengthen the efforts undertaken to develop and manage coastal and small islands of Berau an ongoing basis. If the compilation of zoning is not done holistically with consideration of land suitability will give poor results. This has been pointed out by Crowder et al. (2006) where a lot of use of zoning to determine the utilization of a space such as a conservation area, fishing, and cultivation much done without considering the cumulative impact across sectors.

Coastal and small islands of Berau District totally are an area of about 1.1 million ha, which have a large conservation area of about 257,000 ha. When compared with the total area of coastal and small islands, the area of conservation is about $23 \%$. With the expansion of this magnitude, then the conservation area of Berau is in line with the World Conservation Union, which is recommended to build a world conservation area between $20-30 \%$ of the habitat conservation area should be as no take zone within marine protected area until 2012. The similar case was found by South of Pacific Islands Applied Geoscience Commission (2005) for countries belonging to the Small Island Development State to develop a conservation area by $20 \%$ of the area waters.

The concept of developing large-scale conservation areas is an approach used large marine ecosystem, which is an approach used to determine the extent of a coastal and marine areas for conservation. Large marine ecosystem are defined for coastal and marine area of $200,000 \mathrm{~km}^{2}$ or more that is characterized by depth, hydrografi, and productivity, aspects of anthropology or population (Mahon et al., 2009). This concept has been used about 25 years ago, and has investigated for the impact on coastal and marine ecosystems of the world. This concept is used to address issues of coastal ecosystems in the geographic scale that much influenced by the biophysical aspects. Large marine ecosystem approach is focused on five factors, those are productivity, fish and fisheries, ecosystem health, socio economic and governance of coastal, and marine ecosystems. Several conservation areas following large marine ecosystem approach is a conservation area in the Phoenix Island in the Republic of Kiribati with a $185,000 \mathrm{~km}^{2}$ area, Marine Park Great Barrier Reef Marine with a 344,000 km² area, and the National Marine Park on the Hawaian Island of $362,000 \mathrm{~km}^{2}$ area (Edward, 2008).

Berau conservation areas will be targeted for 17 zones following analysis of conservation targets. In the management of fish resources law and regulation, Government Act No.60/2007 and Fisheries Law No.45/ 2009, distinguish conservation into 3 types, as mentioned in Article 4, namely the conservation of ecosystems, conservation of fish, and fish genetic conservation. Related to ecosystem conservation of fish resources of marine ecosystems, seagrass, coral reef, mangrove, estuary, beaches, swamps, rivers, lakes, reservoirs, embung, and artificial aquatic ecosystem. From 17 conservation target zones, it appears that all of the conservation of ecosystems. Activities performed on ecosystem conservation area is the protection of habitat and fish populations, habitat rehabilitation and fish populations, research and development, utilization of fish resources and environmental services, socioeconomic development, supervision and control; and / or monitoring and evaluation.

\section{CONCLUSION}

Berau Regency coastal and small island zonation plan is one of four coastal and small islands hierarchycal management plan, as stated in Coastal and small islands Law No.27/2007, is an effort or Berau Regency local goverment to manage coastal and small island resources sustainably and with global perspective, with regards of society's aspiration and participation, and national value based on law. It is based on the understanding that coastal and small islands resources are development potential that needs to be protected and utilized for people's prosperity, in this generation and/or the next.

\section{ACKNOWLEDMENT}

The authors would like to thanks for supporting valuable support for this study to joint program of The Nature Conservancy and the World Wild life Fund for Nature Indonesia, Berau Government. 


\section{REFERENCES}

Allen, G. R. 2004. Coral Reef Fishes of Berau, East Kalimantan. T. N. C. Consultancy Report. The Nature Conservancy, East Kalimantan. 51 pp.

Bess, R. \& R. Rallapudi. 2007. Spatial conflicts in New Zealand fisheries: the rights of fishers and protection of the marine environment. Marine Policy. 31 (2007): 719-729.

Crowder, L. B., G. Osherenco, O. R. Young, S. Airame, E. A. Norse, \& N. Baron. 2006. Resolving mismatches in U. S. ocean governance. Science. 313: $617-8$.

Edwards, S. 2008. Ocean zoning, first possession, and Coasean contracts. Marine Policy. 32: 46-54.
Mahon, R., L. Fanning, \& P. McConney. 2009. A governance perspective on the large marine ecosystem approach. Marine Policy: 33: 317-321.

Norse, E. A. 2005. Ending the range wars on the last frontier: zoning the sea. In Norse E. A., Crowder L. B., editors. Marine Conservation Biology: the Science of Maintaining the Sea's Biodiversity. Washington, D. C. Island Press. 422-43.

Wiryawan, B., M. Khazali, \& M. Knight. 2005. Menuju kawasan konservasi Laut Berau, Kalimantan Timur. Status Sumber Daya Pesisir dan proses pengembangannya. Program Bersama Kelautan Berau Mitra Pesisir/CRMP II USAID, WWF, dan TNC. Jakarta. 128 pp. 
